\title{
The potential for solid waste recycling in Urban Area of Tanzania: The case of Dar Es Salaam
}

\author{
Jonas Petro Senzige ${ }^{1}$, Yaw Nkansah-Gyeke' ${ }^{1}$, Daniel O. Makinde ${ }^{2}$, Karoli N. Njau ${ }^{3}$ \\ ${ }^{1}$ School of Computational and Communication Science and Engineering - The Nelson Mandela African Institution of Science and \\ Technology (NM-AIST), Arusha Tanzania \\ ${ }^{2}$ Faculty of Military Science, Stellenbosch University, Private Bag X2, Saldanha 7395, South Africa \\ ${ }^{3}$ School of Materials, Energy, Water and Environmental Science - The Nelson Mandela African Institution of Science and Technology \\ (NM-AIST), Arusha Tanzania
}

\author{
Email address: \\ senzigej@nm-aist.ac.tz (J. P. Senzige)
}

\section{To cite this article:}

Jonas Petro Senzige, Yaw Nkansah-Gyeke, Daniel O. Makinde, Karoli N. Njau. The Potential for Solid Waste Recycling in Urban Area of Tanzania: The Case of Dar Es Salaam. International Journal of Environmental Protection and Policy.

Vol. 2, No. 5, 2014, pp. 147-152. doi: 10.11648/j.jjepp.20140205.11

\begin{abstract}
Recycling and reuse of solid waste has a number of benefits in the overall process of solid waste management. First, it reduces the amount of waste that has to be disposed off; be it in landfills or otherwise. In this way, it reduces constraints on other resources needed in the management of solid waste. Secondly, it is an economic activity through which new enterprises can be created and thus creating employment through collection and reselling recyclable materials, or working directly in the enterprises. In a solid waste characterisation study carried out in Dar es Salaam, it was found that despite the fact that $98 \%$ of solid waste generated per day can be recycled or composted, only $10 \%$ is recycled leaving $90 \%$ to be disposed in dumpsites. This paper we present the results and recommend formalisation of recycling activities in order to reduce solid waste management load to the authorities.
\end{abstract}

Keywords: Recycling, Composting, Solid Waste Characterisation, Dar Es Salaam, Tanzania

\section{Introduction}

Landfill is the traditional way of getting rid of solid waste though other means such as incineration are in use. However, the current trend emphisises approaches that are geared towards avoiding and reducing waste generation as disposal of solid waste can be costly and the waste can have disastrous effects to the environment and peoples' health. As a result, the focus is on composting, recycling and reuse as complementary means to landfilling. Through such means the cost of handling solid waste can be reduced significantly. Besides, such means have other economic benefits as they can be sources of cheaper raw materials for creating new products, create employment through establishment of enterprises for recycling and composting and selling recyclable materials and yet saving the environment and eliminating or reducing health hazards to the people. In fact, according to [1] recycling of materials will conserve resources, save energy and protect the environment, and can often stimulate employment and the local economy. For example, composting can serve as source of organic fertilizers that can feed into initiatives like "Kilimo Kwanza" in Tanzania. In essence, attaching an economic value to some solid waste can save a lot of troubles for the authorities responsible for handling solid waste, the environment and peoples' health.

[3] define waste as 'something for which we have no further use and which we wish to get rid of' and according to [4] it is inclusive of all discarded solid, semi-solid and liquid materials. The aim of this study however, is solid waste (cardboards, organic matter, plastic, textile, metal, construction and demolition waste etc.) and focuses on the potential for reuse and recycling of this kind of waste. Recycling is defined as the redirection of materials from waste stream into the manufacturing, agricultural, horticultural and construction sectors for use in the creation of new products [2]. However, where the waste materials are redirected as delineated in this definition is immaterial. What is important is that waste materials are used in the creation of other new products. Inherent in this redirection 
is that one must know what kind of material is fit for what purpose. That is, characterising the waste materials before deciding what to direct where. [5] argue that knowing the composition of the waste allows for defining the strategies for separation, collection and frequency of collection for recycling. This view is shared by [4] who contend that characterisation and quantification of the waste stream is critical for the successful solid waste management and potential for waste recycling. Furthermore, in a research carried in Mashhad City in Iran about recycling of dry solid waste, [6] noted that the most important of these mechanisms should be the separation of solid waste at the point of generation. The [6] statement is in consonant with the requirements of [7\&8]. Reuse is simply the use of the material again for the original purpose. In this work however, recycling will be used to mean both recycling and reuse. Of course, composting is merely the recycling of organic waste and other biodegradables and thus fits in the earlier definition of recycling.

Solid waste management, being a global environmental challenge [9-13] has attracted a number of researchers. These include researchers on strategies, practices, methodologies and challenges such as [14-31]; on application of various techniques such as Geographical Information System (GIS) [32\&33] and methodologies such as Life Cycle Assessment (LCA) like [34-38]. This category of researchers looks at solid waste from the management point of view. They look at planning mechanism and decisions, methodologies and approaches, techniques and practices geared to proper solid waste management - their failures and successes and room for improvement, cost implications and how they can be minimised, environmental impact of the waste; laws, regulations and directives to that effect.

Yet, some concentrated on modelling and forecasting. This category comprises of the works of [39-52]. This category of researchers is mainly dealing with solid waste generation, factors thereof; solid waste collection optimisation techniques, fleet management and routing mechanisms.

We also have those who specifically dealt with recycling of waste. Such works are accredited to [1-2, 6, 53-61]. These are mainly concerned with the recycling potential, sustainability of the recycling and public awareness and participation. Despite the divergent research interests, all these researchers do agree that "waste is not all waste". Some are valuable and need to be recovered; either as energy or as raw materials for the creation of new products. 4 In this work we look at the recycling potential of the solid waste in urban areas of Tanzania based on a recent research carried in Dar es Salaam.

\subsection{The Current Situation}

The World Bank Report of 2012 estimates that Dar-esSalaam was generating solid waste at a tune of 4200 tonnes per day in 2011 which is equivalent to $0.93 \mathrm{~kg} / \mathrm{cap} /$ day. Of these tonnes only $40 \%$ is collected, about $10 \%$ is recycled the remaining $50 \%$ are buried, burned, or dumped by the road side or into drainage canals. However, the $10 \%$ recycled does not include animal dung that is sometimes used as fertilizers by horticulturalists, gardeners and food remains used to feed dogs and in piggery farms. When taken into account, these wastes may contribute another $10 \%$ of recycled waste. The materials that are usually known to be recycled are plastic and glass bottles, scrap metal, papers and aluminum cans as shown in Figure 1. So far, there has no recycling of ewaste though feasibility study shows that it is a profitable venture. Separation of recyclables suffers from a lack of knowledge regarding identification of materials, and appropriate techniques for handling, sorting, washing and grading.

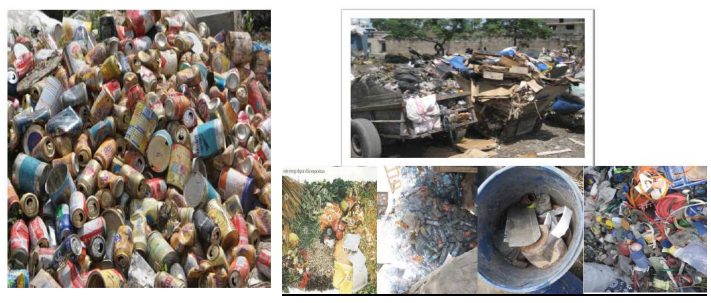

Figure 1. Commonly recycled solid waste types

\section{Methodology}

In carrying out the research, the methodology used by [62] was employed. It involved sorting and weighing directly from the household where solid waste is generated. According to [63] this is an established method for characterising solid waste. The methodology involved the following steps: 1) selecting households for the study; 2) determining the number of samples; 3) sorting and quantifying the solid waste types and 4) analysing the results.

\subsection{Selecting Households for Study}

A total of 639 households were selected from three municipalities of Kinondoni, Ilala and Temeke that make up the city of Dar es Salaam. The number of households was selected proportionally depending on the population and total number of households in each municipality.

Table 1. Demographics of the studied areas and selected samples

\begin{tabular}{llllll}
\hline \multirow{2}{*}{ Municipality } & Wards & \multicolumn{2}{l}{$\begin{array}{l}\text { Population (selected } \\
\text { wards) }\end{array}$} & Households \\
\cline { 3 - 6 } & & TOTAL & SAMPLE & TOTAL & SAMPLE \\
\hline KINONDONI & 3 & 177,599 & 817 & 46,509 & 229 \\
ILALA & 3 & 192,855 & 888 & 51,365 & 253 \\
TEMEKE & 3 & 127,656 & 587 & 31828 & 157 \\
TOTAL & 9 & 498,070 & 2292 & 129702 & 639 \\
\hline
\end{tabular}

229 households were selected from Kinondoni, 253 from Ilala and 157 from Temeke as indicated in Table 1. 


\subsection{Determining the Number of Samples}

The choice of number of samples was solely influenced by solid waste collection trend and the heterogeneity of the solid. Moreover, in the literature there is no specific method used for specifying the number of samples for solid waste characterisation [64]. Since solid waste was being collected from households once a week, we decide to sort and weigh the solid waste generated from each household once a week (a day before collection day) for seven consecutive weeks making it a total of 4,473 (1603 from Kinondoni, 1,771 from Ilala and 1,099 from Temeke) samples from the 639 households.

\subsection{Sorting and Quantifying the Solid Waste Types}

The solid waste was hand sorted and classified into eight categories as shown in Table 2. Sorting was based on the types found most common and those reported in previous studies [62]. The procedure adopted was the same for all waste found in the 639 households for all seven weeks.

\section{Results and Discussion}

Table 3 presents the waste generation rates and composition for the three municipalities. The results are grouped according to municipalities and proportional composition of the various types of waste in terms of percentages. The per capita waste generation rate was found to higher in Kinondoni $1.03 \mathrm{~kg} / \mathrm{cap} /$ day followed by Ilala and Temeke with 0.97 and $0.95 \mathrm{~kg} / \mathrm{cap} /$ day respectively. We also note that the Ilala municipality produces more organic waste $(60.9 \%)$ followed by Kinondoni with $58.6 \%$. A more surprising scenario is that Temeke produces more plastic waste $(21.6 \%)$ compared with Kinondoni (14.4\%) and Ilala (13.2\%). That notwithstanding, plastics waste is the second largest waste produced by all the municipalities. Notably, Kinondoni generates more ewaste compared to Ilala which is a central business district and hence expected to use more eproducts.

Table 2. Classification of solid waste types

\begin{tabular}{ll}
\hline TYPE OF WASTE & WASTE COMPONENTS \\
\hline Organic waste & food waste, garden trimming, wood. \\
any type of polymer content including materials such as PETE, HDPE, LDPE, PVC, PP, and other plastic materials \\
such plastics bags and plastic bottles \\
Plastics & any type of glass bottles, containers, sheets and any other type of glass including broken bottles \\
Glass & any type of paper such as newspapers, wrapping materials, paper packaging materials etc. \\
Paper and cardboards & any scrap metal and aluminum cans \\
Metals & anything electronic such as mobile phones, batteries, TV, computer and computer accessories etc. \\
eWaste & any cloth like material \\
Textile & any other materials whose nature could not be immediately determined. \\
Others &
\end{tabular}

Table 3. Solid Waste Generation by Municipality and Type

\begin{tabular}{|c|c|c|c|c|c|c|}
\hline \multirow{3}{*}{ Type of Waste } & \multicolumn{6}{|l|}{ Municipal } \\
\hline & \multicolumn{2}{|l|}{ Kinondoni } & \multicolumn{2}{|l|}{ Ilala } & \multicolumn{2}{|l|}{ Temeke } \\
\hline & Kilograms & Percentage & Kilograms & Percentage & Kilograms & Percentage \\
\hline Organic Waste & $24,150.00$ & 58.6 & $25,617.00$ & 60.9 & $14,727.00$ & 54.2 \\
\hline Paper and Cardboards & $4,830.00$ & 11.7 & $4,215.00$ & 10.0 & $2,480.00$ & 9.1 \\
\hline Plastics & $5,950.00$ & 14.4 & $5,547.00$ & 13.2 & $5,867.00$ & 21.6 \\
\hline Glass & $3,852.00$ & 9.3 & $4,150.00$ & 9.9 & $2,267.00$ & 8.3 \\
\hline Metals & 923.00 & 2.2 & $1,215.00$ & 2.9 & 952.00 & 3.5 \\
\hline Ewaste & 789.00 & 1.9 & 625.00 & 1.5 & 453.00 & 1.7 \\
\hline Textiles & 293.00 & 0.7 & 284.00 & 0.7 & 273.00 & 1.0 \\
\hline Others & 458.00 & 1.1 & 433.00 & 1.03 & 172.00 & 0.6 \\
\hline Total & $41,245.00$ & 100.00 & $42,086.00$ & 100.00 & $27,191.00$ & 100.0 \\
\hline Generation (kg/cap/day) & 1.03 & & 0.97 & & 0.95 & \\
\hline
\end{tabular}

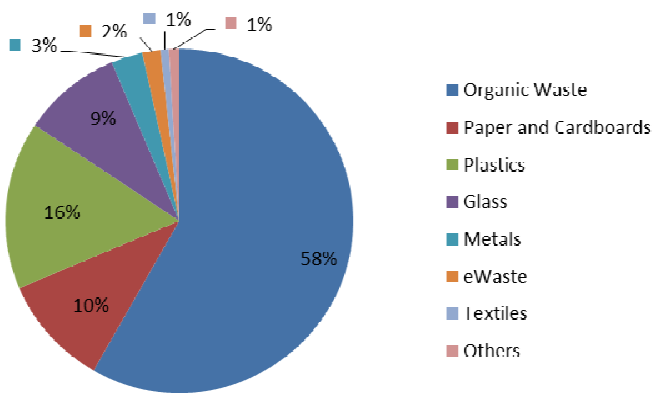

Figure 2. Average percentage composition of solid waste generation.

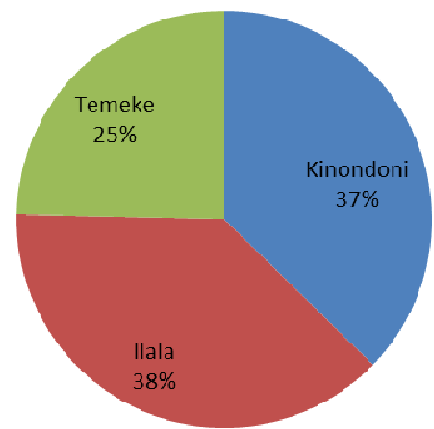

Figure 3. Percentage composition of the recyclables 
Despite the variations in waste constituents in terms of percentages, the solid waste generated by the three municipalities exhibits similar characteristics in terms of the major contents. Organic waste accounts for more than fifty per cent followed by plastics and then paper and cardboards and glass. Figure 2 summarises the results and we find that $98 \%$ (organic waste, paper and cardboards, plastics, glass, metal and ewaste) of the solid waste generated is recyclable. Ideally, this means that if all recyclables were source separated and redirected to create new products the authorities would be remaining with only $2 \%$ to dispose.

The differences in composition of waste generated by the three municipalities can be explained in terms of the differences in consumption patterns derived from the differences in income levels. For example, the Ilala municipality which is the central business district has higher percentage of organic waste due to food wastes resulting from leftovers from hotels and food vending places compared to the other two municipalities In total it has a higher percentage (38\%) of the recyclables followed by Kinondoni with $37 \%$ and Temeke with $25 \%$ as shown in Figure 3.

\section{Conclusion}

The study indicates that solid waste generated in Dar es Salaam has high content of organic waste and recyclables (paper, plastics, glass, metals and ewaste) and all account for $98 \%$ of the total waste generated. Ideally, if all could be recycled the authorities would remain with only $2 \%$ to dispose. Investment in recycling and composting would create employment and engage a good number of the unemployed youth, greatly reduce the quantity of solid waste to be disposed in dumpsites and the cost thereof and encourage source separation as required by the [7\&8]. Moreover recycling will recover raw materials which would otherwise be wasted. We therefore recommend that source separation, composting of the organic waste and recycling of the recyclables should be encouraged and formalised as these would greatly reduce the amount of solid waste to be disposed (to only $2 \%$ ) into the dumping site, hence reducing the cost. This calls for the authorities to enact policies, rules and regulations to that effect. With enabling policies, residents can either as private individuals or through community-based organisations can set up investments for making items like briquettes, paper products like toilet tissues, gift bags, conference folders and even factories for recovering ewaste materials and smelting and molding plastics products. Such initiatives will not be income earning activities, but also reduce waste that must be disposed by municipal authorities and in the process reduce cost on the government. Furthermore, breeding places for mosquitoes and other disease vectors will be reduced and hence save lives which would otherwise be lost due to malaria and cholera. Besides, by setting up a composting facility, the manure will be a good input into urban agriculture.

\section{References}

[1] Read, A.D., 1999. "A weekly doorstep recycling collection, I had no idea we would!" Overcoming the local barriers to participation. Resources, Conservation and Recycling 26: 217-249

[2] Parsons, S., Kriwoken L.K (2010), Report: Maximising recycling participation to reduce waste lo landfill: a study of small and medium-sized enterprises in Horbat, Tasmania, Australia: Waste Management and Research: 28: 472-477

[3] Clarke, M.J., Read, A.D. \& Phillips, P.S. (1998); Integrated waste management planning and decision-making in New York City, Resources, Conservation and Recycling , 26, 125-141.

[4] Supryadi, S., Kriwoken, L.K \& Birley, I. (2000): Solid waste management solutions for Seramang, Indonesia: Waste Management nd Research, 18, 557-566.

[5] Armijo de Vega, C., Benitez, S.O., Barreto, E.R., (2008): Solid Waste characterisation and recycling potential for a university campus. Waste Management, 28 S21-S26.

[6] Farzadkia, M., Jorfi, S., Akbari, H. \& Ghasemi, M. (2012). Evaluation of dry solid waste recycling from municipal solid waste: case of Mashhad City, Iran. Waste Management \& Research 30(1) 106-112.

[7] United Republic of Tanzania Environmental Management Act (2004)

[8] United Republic of Tanzania Public Health Act (2009)

[9] Guerrero, L.A, Maas, G., Hogland, W., 2013. Solid waste management challenges for cities in developing countries. Waste Management 33,220-232

[10] Marshall, R.E., Farahbaksh, K., 2013. Systems approaches to integrated solid waste management in developing countries. Waste Management 33 (2013), 988-1003.

[11] Joseph, K (2002). Perspectives of Solid Waste Management in India. Proceedings of the International Symposium on the Technology and Management of the Treatment \& Reuse of the Municipal Solid Waste, Shanghai, China

[12] African Development Bank, 2002. Study on the Waste Management Options for Africa. Unpublished Report

[13] Achankeng, E. (2003). Globalisation, Urbanisation and Municipality Solid Waste management in Africa. Proceedings of the African studies Association of Australasia and the Pacific, 2003, Africa on a Global Stage

[14] Kuniyal, J.C., Jain, A.P., Shannigrahi, A.S., 1998. Public involvement in solid waste management in Himalayan trials in and around the valley of Flowers, India. Resources, Conservation and Recycling 24: 299-322

[15] Okot-Okumu, J., Nyenje, R., (2011). Municipal solid waste management under decentralisation in Uganda. Habital International 35, 537-543.

[16] Damghani, A. M et al., 2008. Municipal solid waste management in Tehran: Current practices, opportunities and challenges. Waste Management 28: 929-934

[17] Turan, N.G. et al., 2009. Waste management strategies in Turkey. Waste Management 29:465-469 
[18] He, L. et al., 2009. Identifying optimal regional solid waste management strategies through an inexact integer programming model containing infinite objectives and constraints. Waste Management 29: 21-31

[19] Mosler, H.J et al. 2006. Formulating waste management strategies on waste management practices of households in Santiago de Cuba, Cuba. Habitat International 30: 849-862

[20] Bovea, M.D et al., 2010. Environmental assessment of alternative municipal solid waste management strategies: A Spanish case study. Waste Management 30: 2383-2395

[21] Oteng-Ababio, M. 2010. Private sector involvement in solid waste management in Greater Accra Metropolitan Area ni Ghana. Waste Management and Research 28: 322-329

[22] Yedla. S., 2012. Replication of urban innovations prioritisation of strategies for replication of Dhaka's community-based composting model. Waste Management and Research 30(1): 20-31

[23] MacRae, G. 2012. Solid waste management in tropical Asia: What can we learn from Bali? Waste Management and Research 30(1): 72-79

[24] Espinosa, R.M et al. 2008. Integral urban solid waste management program in Mexican University. Waste Management 28: S27-S32

[25] Kaseva and Mbuligwe, 2005. Appraisal of solid waste collection following private sector involvement in Dar es Salaam city, Tanzania. Habitat International 29: 353-366

[26] Mbongwe, B., Mmereki, B.T., Magashula, A. 2008. Healthcare waste management: Current practices in selected healthcare facilities, Botswana. Waste Management 28: 226233

[27] Morrisey, A. J and Phillips, P.S., 2007: Biodegradable municipal waste (BMW) management strategy in Ireland: A comparison with some key issues in the BMW strategy being adopted in England. Resources, Conservation and Recycling 49: 353-371

[28] Read, A.D., Phillips, P., Robinson, G., 1997. Landfill as a future waste management option in England: the view of landfill operators. Resources, Conservation and Recycling 20: $183-205$

[29] El-Hamouz, A.M., 2008. Logistical management and private sector involvement in reducing the cost of municipal solid waste collection service in the Tubas area of the West Bank. Waste Management 28: 260-271.

[30] Tinmaz, E and Demir, I., 2006. Research on solid waste management system: To improve existing situation in Corlu Town of Turkey. Waste Management 26: 307-314

[31] Chung, S.S. and Lo, C.W.H., 2008. Local waste management constraints and waste administrators in China. Waste Management 28: 272-281

[32] Alvarez et al., 2008. Optimising the collection of used paper from small business through GIS technique: The Leganes case (Madrid, Spain). Waste Management 28: 282-293

[33] Van der Meulen, G.G., 2011.Geo-informatics aid to solid waste management for sustainable health safety in urban areas. Journal of Applied Technology in Environmental Sanitation Vol.1(1): 27-43.
[34] Kroneos, C.J. and Nanaki, E.A., 2012. Integrated solid waste management - a life cycle assessment approach: the case study of the city of Thessaloniki. Journal of Cleaner Production 27: 141-150

[35] Gunamantha, M. and Sato., 2012. Life cycle assessment of municipal solid waste treatment to energy options: Case study of KARTAMANTUL region, Yogyakarta. Renewable energy 41: 277-284

[36] McDougall, F.R., 2001. Life Cycle Inventory Tools: Supporting the Development of Sustainable Solid Waste Management Systems Vol. 8(2)

[37] Cherubini. F. et al., 2009. Life cycle assessment (LCA) of waste management strategies: Landfilling, sorting plant and incineration. Energy 34: 2116-2123

[38] Miliute, J. and Staniskis, J.K., 2010. Application of lifecycle assessment in optimisation of municipal solid waste management systems: the case of Lithuania. Waste Management and Research 28: 298-308

[39] Rimaitye, I et al., 2012. Application and evaluation of forecasting methods for municipal solid waste generation in an eastern-European city. Waste Management and Research 30(1): 89-98

[40] Dyson, B and Chang N.B., 2005. Forecasting solid waste generation in a fast-growing urban region with system dynamics modelling. Waste Management 25: 669-679

[41] Fell, D., Cox, J., Wilson, D.C., 2010. Future waste growth, modelling and decoupling. Waste Mnagement and Research 28: $281-286$

[42] Najm, M.A and El-Fadel, M., 2004. Computer-based interface for an integrated solid waste management optimisation model. Environmental Modelling and Software 19: $1151-1164$

[43] Benitez et al., (2008). Mathematical modelling to predict residential solid waste generation. Waste Management 28: S7-S13

[44] Senzige, J.P et al. 2014. Computational Dynamics of Solid Waste Generation and Treatment in the Presence of Population Growth. Asian Journal of Mathematics and Applications Volume 2014, Article ID ama0145, 14 pages ISSN 2307-7743

[45] Huai, X.L et al., 2008. Numerical simulation of municipal solid waste combustion in a novel two-stage reciprocating incinerator. Waste Management 28: 15-29

[46] Sufian, M.A and Bala, B.K., 2007. Modelling of urban solid waste management system: The case of Dhaka city. Waste Management 27: 858-868

[47] Vavilin, V.A. et al., (2004). Modelling Solid Waste Decomposition. Bioresource Technology 94: 69-81

[48] Beigl, P., Lebersorger, S., Salhofer S., 2008. Modelling municipal solid waste generation: A review. Waste Management 28: 200-214

[49] Calabro, P.S. et al., 2011. Modelling biogas extraction at an Italian landfill accepting mechanical and biologically treated municipal solid waste. Waste Management and Research 29(12) $1277-1285$ 
[50] Borgonovo, E., Castings, W., Tarantola, S., 2012. Model emulation and moment-independent sensitivity analysis: An application to environmental modelling. Environmental modelling and Software 34: 105-115

[51] Arribas, C.A., Blazquez, C.A., Lamas, A., (2010). Urban solid waste collection system using mathematical modelling and tools for geographic information systems. Waste Management and Research 28: 355-363

[52] Minciardi, R et al., 2008. Multi-objective optimisation of solid waste flows: Environmentally sustainable strategies for municipalities. Waste Management 28: 2202-2212

[53] Hara, Y., et al., 2010. Current organic waste recycling and potential for local recycling through urban agriculture in Metro Manila. Waste Management and Research 29 (11): 1213-1221.

[54] Ramayah, T., Lee, J.W.C., L.W., 2012. Sustaining the environment through recycling: An empirical study. Journal of Environment Management 102: 141-147

[55] Chao, Y., 2008. Time series analysis of the effects of refuse collection on recycling: Taiwan's "Keep Off the Ground" measure. Waste Management 28: 859-869.

[56] Troscinetz and Mihelcic, 2008. Sustainable recycling of municipal solid waste in developing countries. Waste Maanagement 29: 915-923.

[57] Snyman, J and Vorster, K. 2011. Sustainability of composting as an alternative waste management option for developing countries: A case study of Tshwane. Waste Management and Research 29(11): 1222-1231.

[58] Batool, S.A., Chaudhry, N., Majeed, K., 2008. Economic potential of recycling in Lahore, Pakistan. Waste Management 28: 294-298

[59] Ino, H., 2011. Optimal environmental policy for waste disposal and recycling when firms are not compliant. Journal of Environmental Economics and Management 62: 290-308

[60] Oliveira, C.R., Bernades, A.M., Gerbase, A.E., 2012. Collection and recycling of electronic scrap: A world overview and comparison with Brazilian situation. Waste Management

[61] Shukla, S.R, Harad A.M., Jawale, L.S., 2008. Recycling of PET into useful textile auxiliaries. Waste Management 28: $51-56$.

[62] Gomez G, Meneses M, Ballinas L and Castells F (2008) Characterisation of urban solid waste in Chihuahua, Mexico. Waste Management 28 2465-2471

[63] Tchobanoglous G and Kreith F (2002) Handbook of Solid Waste Management, second edition, McGraw Hill.

[64] Al-Khatib I A, Maria M, Zahra A S F A, Shaheen H Q and Kassinos D (2010) Solid Waste characterisation, quantification and management practices: A case study: Nablus district - Palestine. Journal of Environmental Management 91 1131-1138 